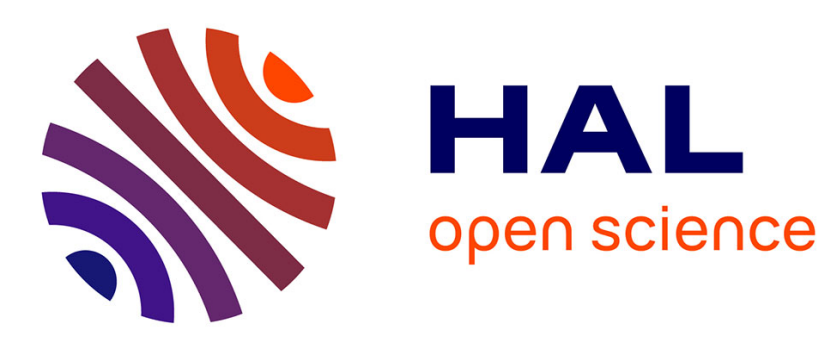

\title{
Chemical Speciation Studies of Radionuclides by XAFS
}

P. Allen, D. Shuh, J. Bucher, N. Edelstein, T. Reich, M. Denecke, H. Nitsche

\section{To cite this version:}

P. Allen, D. Shuh, J. Bucher, N. Edelstein, T. Reich, et al.. Chemical Speciation Studies of Radionuclides by XAFS. Journal de Physique IV Proceedings, 1997, 7 (C2), pp.C2-789-C2-792. 10.1051/jp4:1997237 . jpa-00255316

\section{HAL Id: jpa-00255316 https://hal.science/jpa-00255316}

Submitted on 1 Jan 1997

HAL is a multi-disciplinary open access archive for the deposit and dissemination of scientific research documents, whether they are published or not. The documents may come from teaching and research institutions in France or abroad, or from public or private research centers.
L'archive ouverte pluridisciplinaire HAL, est destinée au dépôt et à la diffusion de documents scientifiques de niveau recherche, publiés ou non, émanant des établissements d'enseignement et de recherche français ou étrangers, des laboratoires publics ou privés. 


\title{
Chemical Speciation Studies of Radionuclides by XAFS
}

\author{
P.G. Allen***, D.K. Shuh*, J.J. Bucher*, N.M. Edelstein*, T. Reich***, M.A. Denecke*** and \\ H. Nitsche*** \\ *Actinide Chemistry Group, Chemical Sciences Division, Lawrence Berkeley National Laboratory, Berkeley, CA 94720 , \\ $U . S . A$. \\ **Glenn T. Seaborg Institute for Transactinium Science, Lawrence Livermore National Laboratory, Livermore, CA 94551 , \\ U.S.A. \\ ****Forschungszentrum Rossendorf, Inst.f. Radiochemie, 01314 Dresden, Germany
}

\begin{abstract}
The local structures of U(VI) oxide precipitates produced as a function of LiOH concentration have been studied by XAFS. Curve-fitting analyses indicate that the solid formed in $0.1 \mathrm{M} \mathrm{LiOH}$ is similar to a schoepite-like phase where distinct linear uranyl ions $\left(\mathrm{UO}_{2}^{2+}\right.$ ) are bridged along the equator by $\mathrm{OH}$ ions. At higher $\mathrm{LiOH}$ concentrations, the uranyl groups become elongated and the precipitate structure resembles that of a uranate salt. We have studied the speciation of Tc in cement waste forms, where it is desirable to stabilize the highly soluble form of $\mathrm{Tc}(\mathrm{VII}), \mathrm{TcO}_{4}^{-}$, by in situ reduction to a less mobile form, i.e. Tc(IV). Using the XANES to measure the oxidation state, our results show that significant reduction takes place in the presence of the cement additives blast furnace slag (BFS) and $\mathrm{Na}_{2} \mathrm{~S}$. In addition, EXAFS data show that in situ reduction leads to formation of $\mathrm{Tc}$ clusters possessing $\mathrm{S}$ and $\mathrm{Tc}$ coordination.
\end{abstract}

\section{INTRODUCTION}

Controlling the transport of radionuclides through the environment requires a detailed understanding of the physical factors and processes that determine an elements' chemical form or speciation. Such knowledge may be used for predictive purposes or to chemically modify the speciation, thereby changing important properties such as toxicity, or solubility. One of the key issues regarding the disposal of radioactive waste is the concern that over long periods of time, radionuclides may leach out of a given waste form and enter the surrounding environment. Uranium and technetium present examples where there is a strong tendency towards formation of the highly oxidized and soluble species, $\mathrm{U}(\mathrm{VI}) \mathrm{O}_{2}{ }^{2+}$ and $\mathrm{Tc}(\mathrm{VII}) \mathrm{O}_{4}{ }^{-}$. Uranium, as $\mathrm{UO}_{2}{ }^{2+}$, will have the propensity to migrate through neighboring acquifers where it can form solid phases which effectively become the secondary source terms. We have previously used XAFS to characterize U precipitates formed in dilute sulfate solutions [1], and in the present study we have extended this work to concentrated LiOH solutions. Leaching of Tc from cement waste forms may be decreased by the used of additives such as blast furnace slag (BFS) which has been proposed to reduce the pertechnetate anion, $\mathrm{TcO}_{4}^{-}$, to a less soluble species such as $\mathrm{TcO}_{2}$ [2]. Herein, XAFS has been used to measure changes in $\mathrm{Tc}$ speciation induced by the addition of different chemical additives [3].

\section{XAFS DATA ACQUISITION AND ANALYSIS}

Uranium $\mathrm{L}_{\mathrm{m}}$ and Tc K-edge XAFS spectra were collected at the Stanford Synchrotron Radiation Laboratory (SSRL) on bending magnet beamline 2-3 using a fully tuned $\mathrm{Si}$ (220) double-crystal monochromator. All spectra were collected at room temperature in transmission geometry using argon-filled ionization chambers and a vertical slit of $0.5 \mathrm{~mm}$. Spectra were calibrated with the reference compounds $\mathrm{UO}_{2}$ (solid) and $\mathrm{NH}_{4} \mathrm{TcO}_{4}(\mathrm{aq}$ ), defining the first inflection points as 17166 and $21044 \mathrm{eV}$, respectively for each reference. XAFS data reduction and non-linear least squares curve-fitting analysis were performed using the programs from EXAFSPAK developed by G. George of SSRL. The theoretical EXAFS modeling code, FEFF6, of Rehr et al. [4] was used to calculate the backscattering phases and amplitudes of the individual neighboring atoms. The amplitude reduction factor, $\mathrm{S}_{0}{ }^{2}$, was held fixed at 0.9 for all of the fits. The shift in threshold energy, $\Delta \mathrm{E}_{0}$, was allowed to vary as a global parameter for all atoms included in the fits (i.e., the same $\Delta \mathrm{E}_{0}$ was used for all shells).

\section{URANIUM OXIDE PRECIPITATES}

All solutions were prepared using $\mathrm{CO}_{2}$-free, deionized water. A stock solution of ${ }^{238} \mathrm{U}$ was made by dissolving uranyl nitrate in concentrated $\mathrm{HCl}(12 \mathrm{M})$ and was purified from daughter activities using an anion exchange column. Five precipitation reactions were performed by mixing $0.1 \mathrm{ml}$ of $2.0 \mathrm{M}$ uranyl nitrate $(\mathrm{pH}=1.0)$ with $2.0 \mathrm{ml}$ of $0.1,0.3,0.5,1.0$, and $5.0 \mathrm{M}$ LiOH stock solutions. The solids precipitated instantly and were recovered as wet pastes ( $10 \mathrm{mg}$ each), mixed with BN, and loaded into polyethylene cuvettes for XAFS measurements.

Figure 1 shows the EXAFS data and corresponding Fourier transforms for the precipitated oxides. The EXAFS spectra show good signal-to-noise which extends the useful range of the data out to $\mathrm{k} \sim 15 \AA^{-1}$. The low-k region is dominated by a low frequency oscillation arising from backscattering of the $\mathrm{O}$ atoms in the linear $\mathrm{UO}_{2}{ }^{2+}$ group. This is demonstrated more clearly 
by the phase-shifted peak at $1.30 \AA$ in the Fourier transforms (FTs). The pattern of FT peaks centered around $1.90 \AA$ in the $0.1 \mathrm{M}$ spectrum is attributed to $\mathrm{O}$ atoms lying in the equatorial plane of the $\mathrm{UO}_{2}{ }^{2+}$ ion. Moving from 0.1 to $0.5 \mathrm{M} \mathrm{LiOH}$, a structural transformation is observed as the $1.30 \AA$ peak broadens, shifts to higher $R$, and the pattern in the equatorial $O$ region is lost. In addition, all of the spectra exhibit a feature(s) at $\sim 3.7 \AA$, which is assigned to $U$ neighbors. The position of the $U$ peak(s) shifts to lower $\mathrm{R}$ upon going from 0.1 to $0.5 \mathrm{M}$. From 0.5 to $5.0 \mathrm{M} \mathrm{LiOH}$, the structures do not show any significant changes.
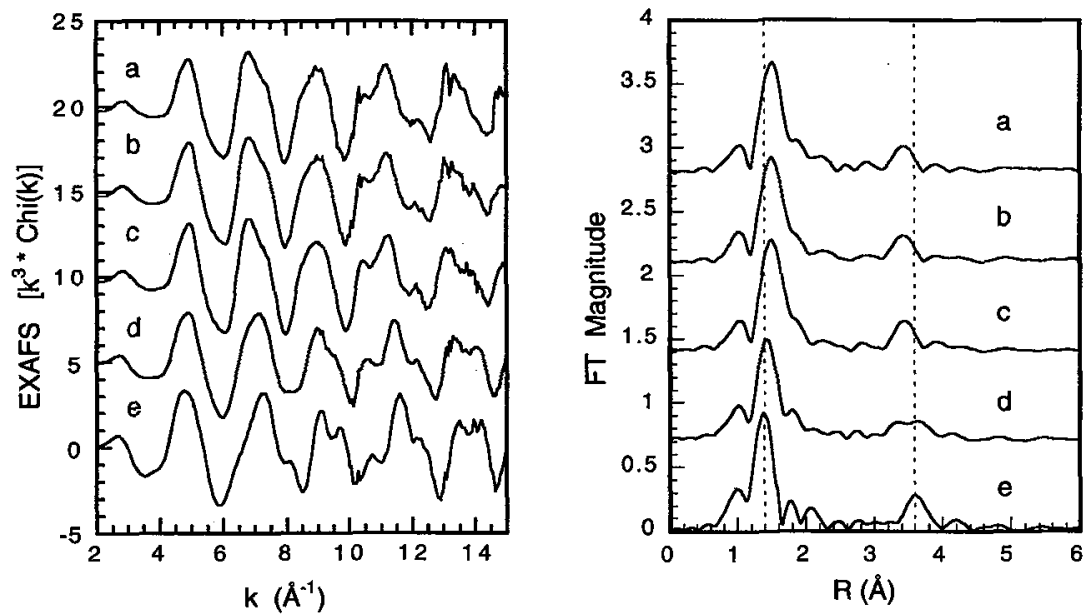

Figure 1: Uranium $\mathrm{L}_{\mathrm{m}}$-edge EXAFS and corresponding Fourier transforms for uranium oxides precipitated in: a) $5.0 \mathrm{M}$, b) $1.0 \mathrm{M}$, c) $0.5 \mathrm{M}$, d) $0.3 \mathrm{M}$, and e) $0.1 \mathrm{M} \mathrm{LiOH}$.

Table I: EXAFS Structural Results for U(VD) Oxide Precipitates

\begin{tabular}{|c|c|c|c|c|}
\hline Sample & Shell & $\mathbf{R}(\AA)$ & $N$ & $\sigma^{2}\left(\AA^{2}\right)$ \\
\hline $0.1 \mathrm{M}$ & $\mathbf{U}-\mathrm{O}_{\mathrm{ax}}$ & 1.81 & 2.0 & 0.0018 \\
\hline \multirow[t]{3}{*}{$\mathrm{LiOH}$} & U-O & 2.26 & 2.7 & 0.0066 \\
\hline & $\mathrm{U}-\mathrm{O}_{\mathrm{eq} 2}$ & 2.47 & 2.0 & 0.0059 \\
\hline & U-U & 3.88 & 2.2 & 0.0052 \\
\hline $0.3 \mathrm{M}$ & $\mathrm{U}-\mathrm{O}_{\mathrm{ax}}$ & 1.84 & 2.0 & 0.0028 \\
\hline \multirow[t]{4}{*}{$\mathrm{LiOH}$} & $\mathrm{U}-\mathrm{O}_{\mathrm{eq} 1}$ & 2.26 & 3.4 & 0.0060 \\
\hline & U-O $\mathrm{eq} 2$ & 2.47 & 1.8 & 0.0139 \\
\hline & U-U & 3.70 & 1.4 & 0.0062 \\
\hline & U-U & 3.92 & 2.4 & 0.0088 \\
\hline $0.5 \mathrm{M}$ & $\mathrm{U}-\mathrm{O}_{\mathrm{ax}}$ & 1.87 & 2.0 & 0.0021 \\
\hline \multirow[t]{3}{*}{$\mathrm{LiOH}$} & $\mathrm{U}-\mathrm{O}_{\text {eq } 1}$ & 2.25 & 4.5 & 0.0086 \\
\hline & U-U & 3.71 & 2.0 & 0.0057 \\
\hline & $\mathrm{U}-\mathrm{U}$ & 4.20 & 2.3 & 0.0116 \\
\hline $1.0 \mathrm{M}$ & $\mathrm{U}-\mathrm{O}_{\mathrm{ax}}$ & 1.87 & 2.0 & 0.0023 \\
\hline \multirow[t]{3}{*}{$\mathrm{LiOH}$} & U-O $\mathrm{O}_{\mathrm{eq}} \mathrm{l}$ & 2.26 & 4.1 & 0.0083 \\
\hline & U-U & 3.72 & 2.3 & 0.0074 \\
\hline & $\mathrm{U}-\mathrm{U}$ & 4.22 & 2.0 & 0.0116 \\
\hline $5.0 \mathrm{M}$ & $\mathrm{U}-\mathrm{O}_{\mathrm{ax}}$ & 1.87 & 2.0 & 0.0019 \\
\hline \multirow[t]{3}{*}{$\mathrm{LiOH}$} & $\mathrm{U}-\mathrm{O}_{\mathrm{eq} 1}$ & 2.26 & 4.4 & 0.0081 \\
\hline & U-U & 3.72 & 2.5 & 0.0080 \\
\hline & U-U & 4.20 & 1.7 & 0.0105 \\
\hline
\end{tabular}

Non-linear least squares curve-fitting was done over the range 1-15 $\AA^{-1}$ on the raw EXAFS data. The bond lengths and coordination numbers are summarized in Table I. Although these samples may contain a mixture of phases, the structural patterns are easily discerned. The $0.1 \mathrm{M} \mathrm{LiOH}$ sample closely resembles the oxide schoepite [1] with $\sim 2 \mathrm{O}$ at $1.81 \AA$, a split shell of $\sim 5$ equatorial $\mathrm{O}$ atoms at $2.26 \AA$ and $2.47 \AA$, and $\sim 2 \mathrm{U}$ at $3.88 \AA$. As the LiOH concentration increases from 0.1 to 0.3 and 0.5 , the axial oxygen bond lengths increase to $1.84 \AA$ and $1.87 \AA$, respectively, while the equatorial bond lengths decrease. 
The shell of $\mathbf{U}$ atoms becomes split over the range $0.3-5.0 \mathrm{M}$, with $-2 \mathrm{U}$ at $3.71 \AA$ and $\sim 2 \mathrm{U}$ at $3.92 \AA$. All of the structural trends observed in the FTs are confirmed by the curve-fitting results.

The normalized $\mathrm{U} \mathrm{L}_{\mathrm{II}}$-edges are shown in Figure 2. The primary absorption peak at $17.17 \mathrm{keV}$ is associated with an allowed $2 \mathrm{p} \rightarrow 6 \mathrm{~d}$ transition. The shoulder that appears at $c a .17 .18 \mathrm{keV}$ has been observed in the $\mathrm{L}_{\text {III }} \mathrm{XANES}$ of numerous U(VI) oxides [6], where it has been proposed to originate from multiple scattering resonances that are associated with the relatively short $\mathrm{U}-\mathrm{O}$ bond interaction of the uranyl group. This assignment has been confirmed more recently by calculations using FEFF6 [7]. As the axial oxygen bond lengths increase, the position of the MS resonance systematically shifts to lower energy, providing another probe for the structural changes in these precipitated solids.

\section{Tc IN CEMENT WASTEFORMS}

The cement wasteform used in this study consisted of a 1:1 wt\% mixture of ordinary Portland cement (OPC) and a simulated waste solution (SWS). The details of the SWS, which is composed of various inorganic salts, have been reported elsewhere [5]. Approximately $1200 \mathrm{ppm}$ of $\mathrm{TcO}_{4}^{-}$(in the form of a $\mathrm{NH}_{4} \mathrm{TcO}_{4}$ stock solution) was added to three separate portions of the OPC/SWS mixture. Cement 1 contained only the OPC/SWS mixture, and Cements 2 and 3 were mixed with $\sim 10$ wt\% of BFS and $\mathrm{Na}_{2} \mathrm{~S}$, respectively. The samples were cured in polystyrene $\mathrm{UV}$-visible cuvettes $\left(4 \times 10 \mathrm{~mm}\right.$ body) for 4 days at $60{ }^{\circ} \mathrm{C}$ under $100 \%$ humidity. Although the edge jumps across the Tc K-edge were less than 0.07 , the extreme homogeneity of these solid solutions enabled data to be acquired in transmission mode. $\left(\mathrm{NH}_{4}\right)_{2} \mathrm{TcCl}_{6}$ solid and $\mathrm{NH}_{4} \mathrm{TcO}_{4}$ (aq) were measured for comparison.

In Figure 3, we show the Tc K-edge XANES spectra for the Tc cement mixtures and the reference compounds. $\mathrm{NH}_{4} \mathrm{TcO}$ displays a prominent $1 \mathrm{~s} \rightarrow 4 \mathrm{~d}$ pre-edge transition (dipole forbidden) which becomes more allowed in the noncentrosymmetric, tetrahedral $\mathrm{TcO}_{4}^{-}$anion. Using this feature as a signature for $\mathrm{TcO}_{4}^{-}$, it is apparent that $\mathrm{OPC}$ does not reduce the pertechnetate anion (Cement 1). The presence of BFS in Cement 2 produces partial reduction while the $\mathrm{Na}_{2} \mathrm{~S}$ in Cement 3 reduces the TcO ${ }_{4}$ completely. These results support the contention that reduced leaching in the presence of BFS is due to Tc reduction by constituents in the BFS, i.e., sulfide-containing species [2].

The correspondence in position and the general shape between the XANES of Cement 3 and $\mathrm{TcCl}_{6}^{2-}$ suggests that the Tc species formed in Cement 3 is a Tc(IV) species, possibly possessing a local structure similar to that of $\mathrm{TcCl}_{6}^{2-}$. This is supported by the EXAFS curve-fitting results for Cement 3 shown in Figure 4. The EXAFS spectra for Cement 2 (not shown) and Cement 3 are dominated by a shell of $S$ neighbors at $\sim 2.4 \AA$. For the BFS-sample, the EXAFS data indicate a residual amount of $\mathrm{TcO}_{4}^{-}$as observed in the XANES. On the contrary, there is no detectable $\mathrm{TcO}_{4}^{-}$in the $\mathrm{Na}_{2} \mathrm{~S}$-sample, and the EXAFS results give $\sim 2 \mathrm{Tc}$ neighbors at $2.80 \AA$. Addition of $\mathrm{Na}_{2} \mathrm{~S}$ leads to the formation of a bridged structure similar to that of $\mathrm{TcS}_{2}$.

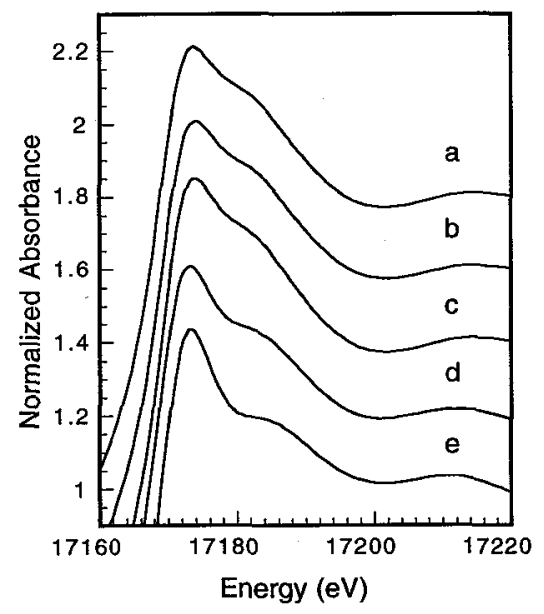

Figure 2: Uranium $\mathrm{L}_{\mathrm{II}}$-edge XANES spectra of uranium oxides precipitated in: a) $5.0 \mathrm{M}$, b) $1.0 \mathrm{M}$, c) $0.5 \mathrm{M}$, d) $0.3 \mathrm{M}$, and e) $0.1 \mathrm{M} \mathrm{LiOH}$ aqueous solution.

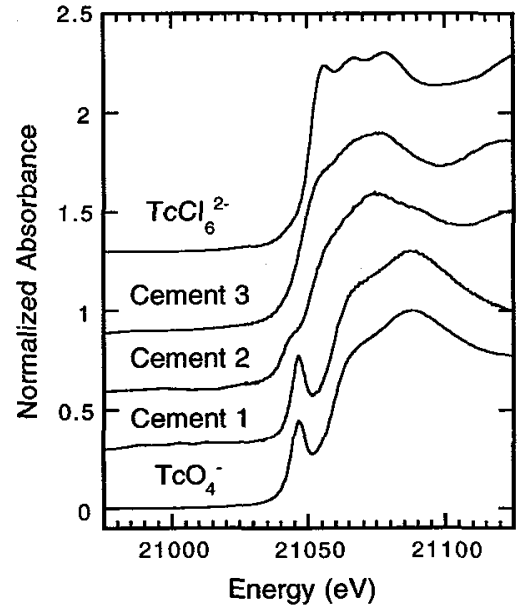

Figure 3: Technetium K-edge XANES spectra of $\mathrm{TcO}_{4}^{-}, \mathrm{TcCl}_{6}^{2-}$, Cement $1\left(\mathrm{TcO}_{4}^{-}+\mathrm{OPC}\right)$, Cement $2\left(\mathrm{TcO}_{4}^{-}+\mathrm{OPC} / \mathrm{BFS}\right)$, and Cement $3\left(\mathrm{TcO}_{4}^{-}+\mathrm{OPC} / \mathrm{Na}_{2} \mathrm{~S}\right)$. 

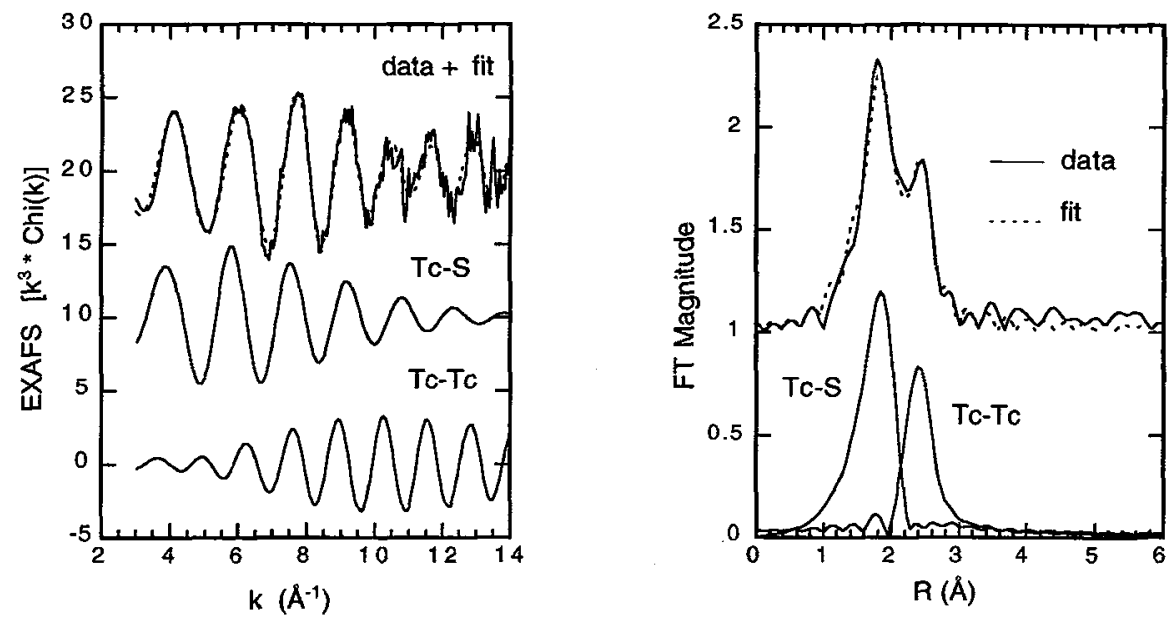

Figure 4: Curve fitting deconvolution of Tc K-edge EXAFS and Fourier transforms for Cement 3 illustrating the presence of the Tc-S and Tc-Tc interactions.

\section{Acknowledgments}

This work was supported by the Director, Office of Energy Research, Office of Basic Energy Sciences, Chemical Sciences Division of the U. S. Department of Energy under contract No. DE-AC03-76SF00098 and by Lawrence Livermore National Laboratory under contract No. W-7405-ENG-48. This work was done at SSRL which is operated by the Department of Energy, Division of Chemical Sciences.

\section{References}

[1] Allen, P. G., Shuh, D. K., Bucher, J. J., Edelstein, N. M., Palmer, C. E-A., Marquez, L. N., Hudson, E. A., Silva, R. I., and Nguyen, S. N. Radiochim. Acta 75, (1996) 47-53.

[2] Gilliam, T. M., Spence, R. D., Bostick, W. D., and Shoemaker, J. L. J. Hazard. Mater. 24 (1990) 189-197.

[3] Shuh, D. K., Kaltsoyannis, N., Bucher, J. J., Edelstein, N. M., et al., "Environmental Applications of XANES: Speciation of Tc In Cement After Chemical Treatment and Se After Bacterial Uptake", MRS Symp. Proc. 344 (1994) 323-328.

[4] Rehr, J. J., Mustre de Leon, J., Zabinsky, S., Albers, R. C. Phys. Rev. B 44 (1991) 4146.

[5] Bajt, S., Clark, S. B., Sutton, S. R., Rivers, M. L., Smith, J. V. Anal. Chem. 65 (1993) 1800.

[6] Petiau, J., Calas, G., Petitmaire, D., Bianconi, A., Benfatto, M., Marcelli, A. Phys. Rev. B 34 (1986) 7350.

[7] Hudson, E. A., Rehr, J. J., Bucher, J. J. Phys. Rev. B 52 (1995) 13815. 